\title{
The Party and \\ Private Entrepreneurs in the PRC
}

HeIKe Holbig

\begin{abstract}
In July 2001, Party Secretary Jiang Zemin announced that private entrepreneurs, among other 'outstanding' representatives of the new social elites, were welcome to join the Chinese Communist Party (CCP). The move led to controversial ideological debates as it was widely interpreted as a clear signal that the communist party was finally turning capitalist. Things become less clear, however, when we look not so much at ideologies but at the actual facts. Realizing how little we know about the reality of relations between the CCP and private entrepreneurs, the aim of the paper is two-fold: The first is to collect and critically assess the information available on current developments of the 'private economy' (a vague notion in itself), and on the proportion of entrepreneurs who are already CCP members. Second, based on this analytical 'deconstruction' of statistical data and categories, the article delineates motives and strategies that might lie behind the new policy of formally admitting private entrepreneurs into the party. As will be argued, one important reason could be that the $\mathrm{CCP}$, by co-opting entrepreneurs, attempts to (re-)gain access to the ever larger labour force employed in the growing non-public sector of the economy and thus to strengthen its organizational presence at the grassroots level. However, while we know something about the CCP's policy, much more needs to be known about the political preferences, attitudes and behaviour of private entrepreneurs. Therefore, instead of drawing macropolitical conclusions, the paper ends with an outline of relevant microscopic aspects of the relations between entrepreneurs and the CCP that deserve more indepth analysis in the future.
\end{abstract}

\section{Admitting Private Entrepreneurs Into the CCP: Does It Make a Difference?}

In his now legendary speech of 1 July 2001, to mark the Chinese Communist Party's 80th anniversary, Party Secretary Jiang Zemin announced that the CCP would open its doors wide to admit 'outstanding elements' from the 'new social strata'. Many observers were surprised by the ideologically acrobatic speech which was purported in the international press to signify a eulogized invitation of private entrepreneurs into the CCP. Particularly in Western countries, the step was interpreted as a heartened acknowledgement by the communist party leadership that the 
country had finally found its way home back into the capitalist world. Strong criticism voiced by alleged 'hardliners' such as Deng Liqun and others who accused Jiang Zemin of betraying the CCP by admitting 'capitalists' and 'exploiters' seemed to confirm that this indeed represented a major breakthrough in the party's ideological and organizational design. ${ }^{1}$

Conventional wisdom had it that the party leadership finally had decided to acknowledge the enormous contributions of the private sector and to broaden its own social base by representing the interests not only of the 'proletariat' but also of the new social elites. This move was said to aim at preventing the defection of a new bourgeois middle class, pre-empting the emergence of a potential political opposition and bolstering the power of the one-party state. With this 'revolutionary' step, Jiang Zemin was seen to have created a personal hallmark that would stand out in party history before handing over the reins to the next generation of leaders.

However, when the moment of surprise was over, observers who looked more closely at the event had to realize that the admittance of entrepreneurs into the party was, after all, not such a new thing. In fact, quite a number of private entrepreneurs seem to have joined the party before, indicating that the CCP doors had actually been open to this group for a while already. As Jiang Zemin's proposal is going to be enshrined officially as the CCP's new policy, it seems worthwhile to test the conventional assumptions and to ask whether it really does make a difference, and, if so, what kind of difference.

To address this question, this paper first seeks to analyse in some depth the various statistical categories and numbers to elucidate the not so clear-cut notions of 'private entrepreneur', 'private enterprise', 'private sector', etc. A second section will piece together the information we have about CCP membership among various kinds of entrepreneurs. Based on these findings, a third section will then discuss various motives and strategies which may be behind the decision of the party to admit private entrepreneurs, and their implications for representing the interests and political participation of the new economic elites. Here, ideological, financial and organizational aspects will be taken into account. It will be suggested that, although there are serious ideological barriers to the inclusion of 'capitalists' into the party, the move can be seen as a rational organizational strategy to secure the CCP's status as 'vanguard of the working class' - albeit with an extended definition of the term. Yet, the main goal of this paper is not to answer questions but to identify relevant new questions and analytical 
topics which could or should be addressed in future research on the relations between the party and private entrepreneurs.

\section{Deconstructing the Private Sector: Categories and Numbers}

At first glance, it seems quite clear what is meant by the 'private sector' in China. As the English language service of Xinhua reported in April 2002, 'the share of the private sector in China's GDP has reached 33 percent, a little lower than the 37 percent of the state-owned economy'. ${ }^{2}$ Unfortunately, as is the case in many English media reports, a definition of the 'private sector' or of 'private enterprise' is not given.

Traditionally, PRC statistics used to differentiate four sectors of the economy by the criterion of ownership of the means of production, namely the state-owned, the collective, the private and the foreignfunded. Among them, the category 'private' was always the hardest to define. In the Chinese language, the term that comes closest to 'private enterprise' is siying qiye, a notion that was sanctioned for official use in 1988 to signify enterprises with privately owned assets employing at least eight people. The latter criterion was to distinguish them from the smaller geti gongshanghu (getihu), the 'single industrial and commercial proprietors' or 'self-employed entrepreneurs' who employ less than eight persons and do not represent formal enterprises in the sense of legal entities. Together, these two categories form the core entities of what is understood as the 'private sector' proper, reported to comprise more than 20 percent of China's GDP. ${ }^{3}$ These 'private entrepreneurs' are still today often imagined as rural and urban self-made men, stereotypically lowly educated but with lots of entrepreneurial wit who have braved the storms of the emerging Chinese market economy.

Statistical numbers for the private enterprises (siying qiye) are the most unambiguous and easy to access. According to official statistics, at the end of 2000, 1.76 million siying qiye were registered across the country, employing 24.06 million persons. ${ }^{4}$ The most recent figure reported for the end of 2001 is 2.03 million private enterprises, an increase which continues the rapid growth trend of the 1990s when the number of private enterprises on average increased by 35 percent per year (see figures below). ${ }^{5}$ Concerning the numbers of self-employed individuals (getihu), official statistics reported a decrease over the past two years: While the number of registered getihu had been growing steadily over the past two decades to reach 31 million in 1999, the figure decreased to 25.71 million at the end of 2000 , and further to 24.23 million at the end 
of $2001 .^{6}$ This reversal of the trend - which seems to be caused by a technical change in statistical recording - has produced no little confusion. Some Chinese sources tend to ignore the decrease and instead extrapolate the former figures; others seem to treat getihu as a residual category; still others exclude the category of getihu altogether without making clear where the 'self-employed individuals' have gone. ${ }^{7}$

Less unambiguous are the data available for the number of people employed in the siying jingji, the 'private economy', comprising both

Figure 1: Number of Registered Private Enterprises (siying qiye), 1989 2001 (in millions)

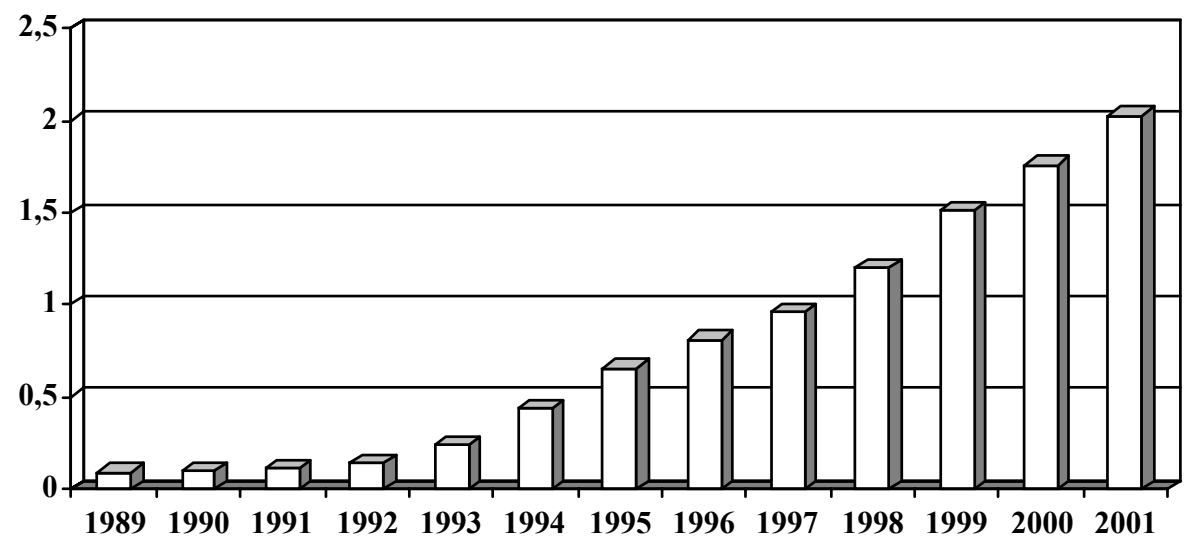

Source: Data made available by the Administration for Industry and Commerce (Gongshangju) in July 2001; data for 2001: Renmin ribao website, 15 September 2002.

Figure 2: Number of Employees in Private Enterprises (siying qiye), 1989-2000 (in millions)

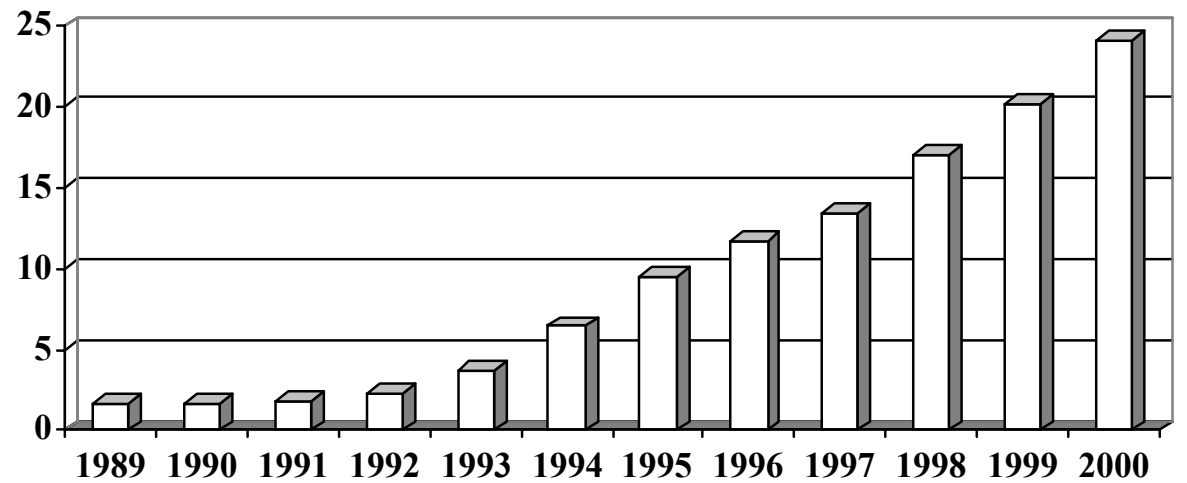

Source: Data made available by the Administration for Industry and Commerce (Gongshangju) in July 2001. 
private enterprises (siying qiye) and self-employed individuals' (getihu) enterprises. Official statistics reported 82.63 million people employed by siying qiye and getihu at the end of 1999, and 74.77 million one year later - the decrease being due to the shrinking number of getihu in the same period. ${ }^{8}$ A recent report published in the official media gave a figure of 74.74 million employees in the private economy for the end of 2001. ${ }^{9}$ Quite differently, an article published in late 2001 in Zhonggongdangshi yanjiu puts the total of people working in private enterprises and self-employed enterprises (jiuye renshu) at 130 million - without explaining how this high number is derived. ${ }^{10}$ Concerning the number of employees in private enterprises (siying qiye), there is also some ambiguity. According to the Statistical Yearbook, in late 2000, one private enterprise employed 13.66 persons on average. ${ }^{11}$ A recent study of the private sector presented by the Chinese Academy for Social Sciences (CASS) reports a ratio of 11.38 employees per private enterprise, based on official registration figures. The same source, however, also cites a nationwide sampling survey which found that one private enterprise employed 55 people on average (with more than 90 percent of them working as low-skilled blue-collar workers in labour-intensive sectors). ${ }^{12}$ Nobody really seems to know how many people are employed in the private economy.

Things become even more ambiguous when alternative concepts of the 'private economy' are taken into account. As a rule, the more ideologically correct a term is, the more statistically vague it becomes. While the term siying jingji (literally 'privately operated economy') is used without much reservation in coastal regions, representatives from less developed regions often prefer the term minying jingji, or 'economy operated by the people', to avoid the capitalist connotations of the word si, private. ${ }^{13}$ Should the minying jingji, at some point in the future, account for the largest share of GDP, then this would be much more palatable than a dominant 'private' (siying) sector.

An ideologically still more cautious notion is the term fei gongyouzhi jingji, or 'not publicly-owned economy'. It defines the private sector in a negative manner, including all ownership forms that are not stateowned, thus comprising not only getihu and siying qiye, but also foreign-invested enterprises and a large variety of mixed ownership forms (among them shareholding companies, 'red hat' and other forms of nominally collective enterprises which will be discussed below). Although these latter types are in many cases actually run as private enterprises, they are not formally acknowledged as belonging to the 'private 
economy' (siying jingi), a term that still is reserved for enterprises with private capital assets of at least 90 percent. Thus, the term fei gongyouzhi jingji is ideologically more correct but statistically less transparent. As parts of the hybrid ownership forms are included, the category produces much higher figures than the category siying jingji. Already in 1996, the fei gongyouzhi jingji was reported to account for 31 percent of industrial output value and 53 percent of consumer goods retail sales; the shares are said to have been growing year by year since then. ${ }^{14}$ According to recent word-of-mouth information, the figures have risen to 38 and 62 percent respectively in 2001.

The statistical deviations between these various categories reflect a high degree of ambiguity in the classification of enterprises. Of course, to some degree the deviations result from the reformulation of statistical concepts in the official process of diversification of ownership forms. However, they are also the outcome of strategies used intentionally by entrepreneurs to cover themselves in a cloak of ambiguity. Various strategies have allowed them to circumvent the discriminations against private firms which, to a greater or lesser degree, are still prevailing today, such as limited access to finance, regulatory restrictions of enterprise size and operation, and ideological harassments by the party-state. Among the most popular strategies have been the following:

- Leasing collective firms: Starting from the early 1980s, many ailing collective enterprises were leased out for private operation. The entrepreneur paid the collective a fixed rent and operated the firm as if it were his own private enterprise. Quite often, these entrepreneurs accumulated large capital assets, thus gradually reducing the share of the collective assets. In some cases, this led to the transformation into a solely privately owned firm. Others, however, preferred to stay in disguise and to continue to operate as leased collectives.

- 'Wearing a red hat': Particularly in the countryside, many firms that were actually privately owned were registered as collectively owned enterprises, among them most township and village enterprises (TVEs, Chinese: xiangzhen qiye). This prevalent strategy of 'wearing a red hat' (dai hong maozi) secured them access to land, assets, finance and markets, as well as tax breaks, favourable contracts, loans on preferential terms or other forms of subsidies by the local governments who, in turn, participated in the profits these firms made. Although local governments started in the middle of the 1990s to encourage the transformation of these firms into private 
enterprises in order to reduce the budgetary costs, 'red hat' enterprises still exist in large numbers today, owing to the continuing advantages of local government involvement.

- 'Roundtripping' of domestic capital: Other domestic entrepreneurs (re)invested their capital on the mainland through offshore companies - often existing as mere 'letterbox companies' in Hong Kong - in order to qualify as foreign investors. As the Chinese government decided very early in the reform process to offer significant tax breaks and other advantages to foreign enterprises (joint ventures or Sino-foreign co-operation enterprises with domestic state-owned or collective enterprises), the roundtripping of capital allowed domestic entrepreneurs to partake in these privileges. With China's accession to the World Trade Organization in 2001 and the application of the 'national treatment' requirement, however, privileges to foreign investors should be reduced considerably over the next years, and with them the incentives for this kind of roundtripping of domestic capital.

- Co-investing with state and collective firms: Last but not least, many private entrepreneurs have decided to co-invest with state or collective firms to create larger mixed-ownership companies, mostly under the legal form of limited joint-stock or shareholding companies. Co-investing with public sector actors may have the advantage of overcoming entry barriers set for private firms in particular sectors (industries considered vital to the national economy; industries whose products entail certain public hazards; and industries using scarce resources - though some restrictions have been abolished during the past two years). Giving shares to local government and party cadres or paying them positions as advisors or board members may also induce other more informal advantages. A Jiangsu entrepreneur explained in an interview in Spring 2001 how he had tactically and elegantly distributed the shares of his firm between his wife, various other family members and key figures in the local government, not neglecting the local community authority which obtained 0.5 percent of his company's shares.

These strategies demonstrate that the private sector in China is far from presenting a clear-cut entity. Instead, the regulatory and ideological restrictions confronting private entrepreneurship have produced many incentives to create tactical ambiguity about the firm's ownership form. The more successful private entrepreneurs are, the more they will be inclined to obscure their categorization as part of the 'private 
sector' and to join the hybrid sector of mixed ownership and management forms. To tackle this ambiguity, administrators have started to give up the increasingly obsolete ownership categories and instead to lump the various categories together by simply distinguishing between 'small and medium enterprises' (zhong xiao qiye, which are reported to make up 80-90 percent of Chinese enterprises) and 'large enterprises' (most of which are state-owned enterprises). ${ }^{16}$ Although this might be a more realistic approach, it does not help to clarify the existence of 'true private entrepreneurship' in China.

David Goodman presents an even more disturbing message. In a study on entrepreneurs conducted during 1996-98 in Shanxi province, he argues that a complex sector of the economy has emerged between the state-planned and the privately owned sector which has to be acknowledged as a key feature of provincial economic development. Apart from the traditional state-run enterprises on the one side and the formal private sector enterprises on the other, a hybrid variety of ownership structures, management systems, registration and incorporation systems and scales of operation has sprung into existence over the past decade. Goodman characterizes this hybrid sector as the new 'public sector' of the economy in the sense that it is relatively open to market forces and public equity. Among them, he identifies:

- urban enterprises including collectives and share-based companies established by state-run enterprises and social units, as well as urban collectives of more pre-reform types;

- rural enterprises including collectives and stock companies established by townships, villages and rural districts, taking advantage of the rural sector's preferential economic regulations;

- wholly or partly foreign-funded enterprises, often former private sector or state-run enterprises which have been transformed into larger firms through foreign investment;

- so-called 'public sector private enterprises' private enterprises which have become either collective enterprises through co-operation with local governments or which have become share-based public companies, but where the original individual entrepreneur remains in the senior management position.

Looking at the personal backgrounds and risk-taking approaches among the entrepreneurs and managers of the different types of staterun, private and 'public sector' enterprises, Goodman concludes: 
Indeed, whilst entrepreneurship is certainly to be found in the private sector of the economy, the more successful entrepreneurship is located outside the formal private sector in the new hybrid series of arrangements that exists between the state-run and private sector. ${ }^{18}$

With this finding, Goodman indeed shakes the myth of the dynamism of the private economy contrasting with the inertia of the public economy. According to his study, the most outstanding entrepreneurs are to be found not in the private sector but in the hybrid public-private ownership sector. If his observation is true not only for Shanxi province but for other regions too, then the question arises: Who exactly does the CCP leadership have in mind when extending the invitation to join the party? The question becomes all the more tricky when we realize that a large number of entrepreneurs are already in the party.

\section{Who is Co-opting Whom? Party Background of Entrepreneurs}

Statistics on the percentage of party members among entrepreneurs are available but rather scattered. Relevant data can be found in the secondary literature of the past years and in some recent official and semiofficial Chinese publications.

Starting at the bottom end of percentage shares, Andrew Walder found in a nationwide representative sample conducted in 1996 that 2.6 percent of those classified as getihu and 14.8 percent of private entrepreneurs (obviously siying qiye) were party members. ${ }^{19}$ These numbers seem quite low, but things look different when we take the firms' scale of operation into account. As various business associations are competing with one another at the local level to induce the larger and more 'representative' enterprises to become members, their membership data are quite revealing here. In particular, the All-China Federation of Industry and Commerce (ACFIC) and its provincial and local subsidiaries (also called minjian shanghui or 'non-governmental chambers of commerce'), which have been mandated by the CCP's United Front department specifically to represent the private sector enterprises, offer relevant information. Thus, recent ACFIC data reveal that the share of CCP members among its own members has already increased beyond 20 percent. For Anhui province, the provincial chamber data set for 2001 gives a number of 22 percent of member entrepreneurs who belong to the party. ${ }^{20}$ These numbers are confirmed by other recent Chinese data. The Almanac of Private Economy in China 2000 reported that 19.8 percent (or 4.3 million) of China's private entrepreneurs (obviously siying qiye) in 1999 were party members. ${ }^{21}$ 
Still higher shares of party members have been reported by Bruce Dickson, who conducted a survey in eight counties in Zhejiang, Shandong, Hebei and Hunan in 1997 and 1999 which included, among others, more than 500 private entrepreneurs. In this survey, which was not conceived as a random sample but intentionally designed to represent the local economic and political elites, Dickson found that almost 40 percent of all responding entrepreneurs were already CCP members; among them, 24.6 percent were xiahai entrepreneurs, or former officials who had left their posts and 'plunged into the sea' of the private economy; 13.4 percent were formal private entrepreneurs who had been co-opted into the CCP as a result of their business success at some point in the past. Among the members of various business associations, he found the highest percentage shares of CCP members among members of local subsidiaries of the ACFIC; among them, 34.7 percent had a background as xiahai entrepreneurs and 16.8 percent as private entrepreneurs who were later co-opted into the $\mathrm{CCP}$. Together, more than half of the responding ACFIC members were $\mathrm{CCP}$ members when the survey was conducted. Also quite strikingly, more than one-quarter (26.7 percent) of the entrepreneurs in the sample responded that they wanted to join the party, with about the half of them having applied for CCP membership already. ${ }^{22}$

As we understand now, growing numbers of entrepreneurs had de facto been admitted as party members at the local level by various 'flexible methods' (biantong fangshi) since the $1980 \mathrm{~s}^{23}$ - despite the fact that Article 1 of the CCP statute excludes entrepreneurs as possible CCP members, and despite a Central Committee document of 1989, which explicitly banned private entrepreneurs from joining the party (see below). Municipal and county party committees decided high-handedly to recruit local magnates for pragmatic reasons - be it to participate more effectively in the wealth of private entrepreneurs, or because they realized that they could not find enough competent people to run as village party secretaries if they excluded private entrepreneurs. In order to circumvent the official ban, some private entrepreneurs signed their firms over to their spouses and applied for party membership as 'employees' of their own firm. ${ }^{24}$

Percentage shares rise further when we do not focus on the formal private sector, but look at the various hybrid enterprise forms identified above. Many of these hybrid enterprises are not run by entrepreneurs in the sense of private owner-operators but by managers taking entrepreneurial risks and contributing with entrepreneurial skills. It seems to be this wider group of managers and entrepreneurs in the 
hybrid private-public sector which Jiang Zemin had in mind when he invited into the CCP 'outstanding elements' of the 'new social strata'. In his speech, he named 'among others, entrepreneurs and technical personnel employed by scientific and technical enterprises of the non-public sector, managerial and technical staff employed by foreign-funded enterprises, the self-employed, private entrepreneurs, employees in intermediaries, and freelance professionals'. ${ }^{25}$

In the above-mentioned study conducted by David Goodman among Shanxi business people, he found that 39 percent of owner-operators in the formal private sector (many of them confirming the stereotype of young and lowly-educated self-made men) were CCP members. While this share is already high, he found significantly larger shares among the generally better educated, and sometimes older, managers and entrepreneurs in what he identified as the hybrid 'public sector'. Thus, 71 percent of urban enterprise managers, 77 percent of rural entrepreneurs, 73 percent of joint venture managers and 56 percent of 'public sector private entrepreneurs' were found to be party members. Also, among the mostly young and highly educated people who were hired by formal private enterprises as managers due to their specialized professional skills, 66 percent were CCP members; all of them had entered the party after $1978 .{ }^{26}$

The above-mentioned Research Report on Social Strata in Contemporary China published by CASS in late 2001, which is based on samples from four different localities in China, offers some revealing and somewhat surprising information in this context. The study found that the share of CCP members ranged between 5.2 and 13.7 percent among self-employed entrepreneurs, and between 0 and 24.4 percent among private entrepreneurs (with 85.2 percent of private entrepreneurs in Shenzhen found to be members of the Communist Youth League, the CCP's traditional recruitment pool). Strikingly, the figures are significantly higher among managers (jingli renyuan): here, shares of CCP members vary from 35.7 to 58.8 percent (with a record high of 97.1 percent of managers in Hefei, Anhui province, found to be present or former members of the Communist Youth League). Clearly, these percentage shares are much higher than among industrial workers, where the share of CCP members ranges between 5.9-13.3 percent, and among agricultural workers with a range of 4.3-5.2 percent). ${ }^{27}$

Confronted with these figures, and recollecting the fact that the ratio of CCP members among the overall populace is less than 5 percent, the party seems to have attracted managers and entrepreneurs quite successfully in the past already. Why, if the new economic elites - or, at 
least, their most outstanding representatives - are already party members, should the CCP be interested in 'opening the doors wide' to the 'new social strata' in the future?

\section{Ex-post Legitimization of a Long-standing Fact: Ideological Strategies}

The simple answer to the question why private entrepreneurs are now officially admitted into the CCP is that the party leadership is attempting to legitimize what has already been occurring for many years. The need for an ex-post legitimization might have seemed all the more pressing as the ideological revaluation of private entrepreneurs has been increasingly lagging behind the rise of their constitutional status in recent years. Since the start of economic reforms, the most important steps in the constitutional career of the private sector were the recognition of individual economic activities as being complementary to the state sector in 1982, the recognition of the private economy as being a complement to the socialist public economy in 1988, and the recognition of the private economy (feigongyouzhi jingji) as an 'important component of the socialist market economy' (shehuizhuyi shichang jingji de zhongyao zucheng bufen) plus the provision of constitutional protection of this sector (Art. 11) in 1999.

Party ideology with its inbuilt safeguards against 'capitalists', 'exploiters' etc. found it hard to parallel the steady economic and constitutional rise of the private sector, although there were some earlier attempts to bolster the ideological status of private entrepreneurs. During the 13th Party Congress in 1987, Zhao Ziyang, then General-Secretary of the CCP, arranged for the 'Guan Guangmei phenomenon' to be presented as a showcase to the public. Guan Guangmei was a Liaoning party member who had taken the lead in leasing an ailing state-owned enterprise and turning it into a profitable private enterprise. Since then, private entrepreneurs started to join the party in significant numbers, provoking an intra-party controversy on the topic of 'exploitation'. ${ }^{28}$ The Tiananmen protests in 1989 caused a setback; in August of this year, the Central Committee published its Document 1989 No. 9, which explicitly banned private entrepreneurs from joining the CCP (Jiang Zemin, then incoming Party Secretary, supported the ban explicitly at the time). Starting in the early 1990s, Deng Xiaoping helped to step up the political status of private entrepreneurs. In his theory of the 'three benefits' (sange liyu), which was also incorporated in the official document of the15th Party Congress in 1997, he argued that the standard to measure whether an 
ownership system was good or bad was 'whether or not it benefits the development of productive forces in a socialist society, the improvement of overall national strength, and the improvement of people's lives. ${ }^{29}$ What he refrained from doing, however, was establishing criteria for representatives from the private sector to qualify as CCP members.

Since early 2000, when Jiang Zemin introduced to the public the socalled 'requirements of the three representations' (sange daibiao), he has paved the way for a full ideological emancipation of private entrepreneurs. Claiming that the CCP has always to 'represent the development trend of China's advanced productive forces (1), the orientation of China's advanced culture (2), and the fundamental interests of the overwhelming majority of the people in China (zui guangda renmin de genben liyi) (3)', he builds upon Deng Xiaoping's 'three benefits'. By putting the stress of the argument on the development of the 'productive forces' (1), attention is shifted away from the notion of the 'relations of production', which, according to Marxism-Leninism, creates the contradictions between classes and determines whether a social system is either capitalist (exploitative) or socialist (non-exploitative). By actively supporting the development of the most 'advanced' production forces, class struggle becomes irrelevant. The other crucial manipulation of party ideology is the notion of the 'overwhelming majority of the people' which the CCP is required to represent. As sensitive readers in China seem to have understood very early on, this notion - which at first glance simply seems to reaffirm the CCP's 'mass line' idea - has been intentionally formulated by Jiang Zemin to include basically all social classes, or, as the concept of 'class' has been made irrelevant, all social strata. ${ }^{30}$

Also, obviously in an effort to bolster the image of private entrepreneurs who are still widely seen as stingy rustics with a low 'cultural calibre' (wenhua suzhi), a hierarchy is being created among new social strata: Situated at the top of this hierarchy are 'entrepreneurs and technical personnel employed by scientific and technical enterprises of the non-public sector'. Next come 'managerial and technical staff employed by foreign-funded enterprises', and only then are the self-made type of private entrepreneur, the self-employed and others mentioned. This preoccupation with the higher realms of science and technology (S\&T) seems to resonate with older mystical beliefs in the modernizing power and scientistic debates of the late nineteenth and the early twentieth centuries in China. This aspect becomes very obvious in a Qiushi article of November 2001, which describes the 'key contribution' of the new social strata to the 'building of a socialist economy': 
The broad masses in the new social strata are all engaged in economic operations to adapt to the objective needs of the development of a socialist market economy. Private S\&T enterprises and their leading technicians with their flexible and efficient operating forces are engaged in market economy operations, with their entrepreneurs and technicians applying leading S\&T to the development of new products.... The broad masses in such new social strata are playing a key role in promoting S\&T progress, revitalizing the market, optimizing the disposition of resources, expanding job avenues, meeting diverse social needs, and increasing overall social productivity, to promote the development of the national economy. ${ }^{31}$

Perhaps the most important element in this legitimization strategy is the establishment of a set of criteria for admitting entrepreneurs into the party. Here, the somewhat tautological formula presented in Jiang Zemin's July speech goes: 'The main criteria to admit a person into the Party are whether he or she works wholeheartedly for the implementation of the party's line and programme and meets the requirements for party membership. ${ }^{32}$ This formula obviously was regarded as too vague; consequently, party organs in the following months set out to clarify the criteria for party membership. Thus, at the end of August, a much more specific set of requirements was made public. According to a Xinhua report, entrepreneurs who wanted to join the party would have to (1) be law-abiding patriotic citizens, (2) not be guilty of tax-evasion, (3) reinvest the major part of their profits, and (4) to repay society out of the wealth they have accumulated. ${ }^{33}$ Here, the delegation of socio-economic responsibilities to the 'new rich' appears as an important rationale behind the move to invite entrepreneurs into the CCP.

Another Qiushi article of November 2001 offers a major discussion of the criteria of party membership, recommending rules to establish a person's qualification to join the party. The core passage goes:

The introduction of these principal criteria for recruiting new party members requires that we be strict in guarding the gates to the party as well as the gates of ideology. ... The two basic requirements of "wholeheartedly struggling for the implementation of the party's line and programme" and of "meeting the requirements for party membership" should be handled as one single criterion; observation of practical performance, as well as the motive for joining the party, should be integrated, while one-sidedness should be avoided. ... Efforts should be made to strictly prevent those with impure motives from being admitted into the party and to avoid using erroneous methods to measure the new requirements for party membership, such as admission based on economic strength, on the amount of material donation to society, and on personal reputation. ${ }^{34}$ 
The main thrust of this argument seems to be to pacify those who fear that the CCP might admit persons simply for the sake of their wealth and business success, or persons whose main motive is to abuse the party's organizational network for their own commercial interests - a fear that seems quite reasonable. The attempt of ideological justification comes very close to more pragmatic motives of admitting entrepreneurs into the party, which will be discussed below.

The CCP leadership is conscious of the fact that many regard the party's efforts to justify itself ideologically as highly cynical. As Børge Bakken points out, the 'three representations' imply the revision of the Marxist theory of labour and labour value which has formed the core theory of Marxism and thus lie at the heart of the CCP's identity as the 'vanguard of the working class'. ${ }^{35}$ The fundamental contradiction between 'capitalists' and 'proletarian masses', between 'exploiters' and 'exploited', which has been internalized in China's socialist discourse over decades, clearly stands in the way of accepting the CCP's new claim to represent both - labour and capital, workers and entrepreneurs. Party theorists and social scientists have recently collaborated intensively to find a formula to reconcile the contradictions, at least rhetorically, and they have come up recently with a pair of innovatively coined concepts. Workers and peasants are classified as 'basic labourers' (jichu laodong), while entrepreneurs and managers, the new economic elites, are coined as 'management labourers' (guanli laodong, or jingying guanli laodong) with their specific, and in fact, qualitatively more valuable contributions to social and economic progress. The CCP of course, according to its traditional mission as the 'vanguard of the working class', has to represent all workers of the modern economy, basic labourers as well as management labourers. ${ }^{36}$

Whether one reads this formula as an enlightened departure from Marxist dogmatism or as pure cynicism depends on one's own ideological standpoint. Theoretically, the concept of social(ist) democracy, which has been debated in Chinese leadership circles for several years, could offer a framework for a broad representation of all social strata in the CCP. Yet, acceptance of the new formula should hinge not so much on the adequate use of ideological labels but on the perception of real opportunities. Even those social groups who have lost out most in the reform process would probably not cite the classical Marxist concepts of exploitation of surplus value to prove the party regime wrong, but rather demand that they themselves, or their children, get better chances to participate in the country's economic growth and catch up with the 
new economic elites whatever they are called. Here, I would argue in line with Torstein Hjellum that the party regime will have a basis of legitimacy as long as it allows sufficient upward mobility for workers and peasants to enter the elite ranks. ${ }^{37}$ However, should the 'three representations' aim not so much at opening the party up to the 'new social strata' but rather, as Børge Bakken suggests, at 'closing the door to groups further down in the social hierarchy', ${ }^{38}$ then the CCP's basis of legitimacy may indeed crumble rapidly.

\section{Repaying Society: Material Motives}

Considering more pragmatic reasons for the CCP to invite entrepreneurs, of course, one would first of all think of financial motives. As it is always advantageous to be in the company of rich people, local party committees might wish to participate more in the wealth of the new economic elites and the charisma that radiates from it. More specifically, while the party-state as a whole will not have any difficulty in financing its own activities, it should be interested in devolving some of its social tasks to the newly rich.

Thus, in the first half of 2001, chambers of the All-China Federation of Industry and Commerce mobilized their members to take part in a public relations campaign titled 'Two think-ofs' (liang si). With its motto 'Being wealthy, yet think of the sources [of wealth], enjoying prosperity, yet think of development', the campaign appealed to private entrepreneurs to be cognizant of their social responsibility and pay their share for social, educational, cultural and infrastructure projects in their communities or in other parts of the country - some in the far West. The so-called 'Glorious Cause' (guangcai shiye) activities organized by party and mass organizations and financed by more or less voluntary philanthropists among the newly rich have, in the meantime, grown into a nationwide network which involves significant 'private' financial transactions. ${ }^{39}$

Also, by inducing more private entrepreneurs into the reach of the party-state, some might hope to improve the tax discipline of the new economic elites. While tax evasion seems to have been a kind of sport among private and self-employed entrepreneurs since the 1980s, the state has tried since the mid-1990s to consolidate the legal basis of tax collection in the private and the hybrid public-private sector, but with mixed success. Although private enterprises and individually owned enterprises together account for more than 20 percent of GDP, they are reported to contribute less than 10 percent (in some places less than 5 percent) to the local coffers. ${ }^{40}$ 
Connected with these financial aspects is the fear of some that admitting private entrepreneurs into the CCP will strengthen the role of 'money politics', making corruption even more widespread than it already is. ${ }^{41}$ As the above-mentioned CASS report complains, there are already quite a number of private entrepreneurs who regard themselves as 'special citizens' (teshu gongmin) or are so regarded in their local communities. Thus, they bribe local officials in order to obtain 'political loans' (zhengzhixing daikuan) and other preferential treatment, and show off their wealth through conspicuous consumption, which leads to moral decay. Some of them even link up with triads and other criminal organizations, exerting a very bad influence on local politics. ${ }^{42}$ Of course, with more financial capacity entering the party, to fear that this will inflate corruption seems a legitimate concern. On the other hand, one could argue that, compared to the bribery and red-tape practised at present, corruption will not necessarily increase in the wake of more entrepreneurs joining the party. As entrepreneurs will not have to 'take the back entrance' (zou houmen) but will be able, as party members now themselves, to 'take the front entrance' ('zou qianmen') to realize their goals, overall corruption may well diminish and 'money politics' may become more transparent than it used to be in the past.

\section{Co-opting the New Elites: Strategies of Inclusion}

Another prevailing argument is that the admission of entrepreneurs into the CCP is to be interpreted as a strategy to co-opt the new elites: a strategy of inclusion that allows an organization to add new skills and resources, enhance its performance, increase political support etc., thereby 'avert[ing] threats to its stability or existence'. ${ }^{43}$ According to this interpretation, by incorporating private entrepreneurs, the party mitigates the political pressures from these people. By bestowing on entrepreneurs the prestige of being part of the ruling party and giving them a say in decision-making, the CCP ultimately aims at preventing the emergence of a bourgeois middle class which could form an autonomous political force and thus challenge the CCP's power. In a word, the co-optation of new economic elites is designed to pre-empt a potential political threat which a future middle class or bourgeoisie could pose to the CCP's one-party dominance. ${ }^{44}$

This argument is used by CCP ideologues, too, whose mission is to promote the admission of the new 'outstanding elements'. Thus, some of them warn that if the party does not reach out to the new elites, they could, at some point in the future, form an organized oppositional force 
challenging the party's authority. As one article published in late 2001 in Zhonggongdangshi yanjiu argued, the CCP has to learn a lesson from the worldwide decay of communism: The reason why the power of the Soviet Union's and other countries' communist regimes collapsed was the fact that they had failed to adapt their social base in accordance with the structural change of the social strata, thus 'losing the support of the youth, particularly of young entrepreneurs active in the new economy and of young intellectuals'. To prevent a collapse of power similar to that of the Soviet Union, the CCP should follow the trend of the more successful socialist democratic parties worldwide and adapt its social base to absorb outstanding elements from the newly emerging middle strata (xinxing zhongjian jieceng), among them entrepreneurs, white-collar workers and intellectuals. Should the party fail to do so, the author warns, these people 'will necessarily develop this or that idea' (shibi hui chancheng zheyang nayang de xiangfa), some will join one of the democratic parties, or even join forces with other parties to form an opposition party (chengwei yige fanduipai)'. ${ }^{45}$

Now, we should ask ourselves how realistic such a scenario is indeed. More specifically, is there really something like a new middle class in the making, with an independent bourgeois mindset and political ambitions of its own, which the party has to prevent from taking over its power? As we have seen above, there are large differences in the social, educational and professional backgrounds of the various groups of entrepreneurs and managers, with the sidewalk shoeshine getihu at one extreme, and the US-trained manager of a modern 'S\&T' enterprise, investment corporation or foreign-invested firm at the other. Also, the oft-cited discrimination against the private economy does not apply uniformly across the various ownership and management forms. While some enterprises may find it hard to access bank credit, land or raw materials, others may have found a viable mode of symbiosis with the local authorities which secures them privileged access to finance and other resources as well as political insurance. With the enormous differences in mind, it still seems hard to imagine the emergence of a homogeneous social group pursuing a collective set of strategies in a consistent manner, at least for the time being. As Bruce Dickson maintains: 'So far, China's private entrepreneurs have not asserted themselves as an organized or coherent interest group. ${ }^{146}$

Yet, according to the CASS report, a social identity of private entrepreneurs is in the making. Although they do not yet form a political force of their own, private entrepreneurs are found to gradually de- 
velop a sense of common bonds and belonging. What binds them together is, after decades of repeated class struggle, the desire to regain full social and political acceptance as well as legal protection of their properties and activities. Only if they can trust that the severe ideological discrimination against 'capitalists' in the past will not be repeated in the future, the report argues, will entrepreneurs be ready to reinvest substantial parts of their profits. Also, the study finds, while the majority of entrepreneurs are restricting their activities to speaking business (zai shang yan shang), aiming just to protect or promote their individual status, a minority has become politically active, articulating specific political demands. Thus, for example, they lobby for a positive business environment and a stable implementation of economic policies, for the enhancement of their social and political status (e.g. for the right to be eligible as 'model workers'), for legal guarantees and for more direct participation in the party-state's decision-making process. ${ }^{47}$

If these findings are true, a rationale might indeed have taken shape in CCP leadership circles to include the more active and articulate elements among the new social strata into the party rather than risk their political defection. However, we have to ask ourselves again whether the new policy of admitting entrepreneurs into the party does indeed make a difference here. Inclusionary politics have been practised by the party-state in the past. Various mechanisms of inclusion have existed for a long time, such as 'arranging' (anpai) for entrepreneurs to serve as delegates to people's congresses or the political consultative congresses at all administrative levels, to let them articulate their interests via the ACFIC and its local subsidiaries, or via other associations and mass organizations, etc. Strikingly, many of these traditionally 'arranged' political representatives of the private economy are already CCP members - which can be easily explained by the fact that it is always the most prestigious entrepreneurs who are selected for 'political' posts. As Bruce Dickson found in his sample of eight counties, 78 percent of private entrepreneurs in people's congresses and 61 percent in political consultative congresses were party members. ${ }^{48}$ Therefore one could argue that the strategy of co-optation has been applied quite successfully already.

Given such a high degree of overlapping political roles among private entrepreneurs, the question arises whether the admission of more entrepreneurs into the CCP might not merely lead to a duplication of leverage of those groups who have already been politically active in the past. Of course, the new policy would make a difference if it were to allow representatives of the private sector to take over politically influ- 
ential party or government posts. Otherwise, bestowing the most prestigious private entrepreneurs with CCP membership, for them could just mean another honorary ornament without much significance for political participation. Much more detailed information will be needed to find out more about the reality of inclusionary politics vis-à-vis the private sector.

\section{Stretching the CCP Grassroots: Organizational Motives}

Another - more tangible and perhaps more decisive - motive for inviting private entrepreneurs into the CCP may be the steady decline of the party's organizational influence in the economy which has been recorded over the past two decades. In the traditional state-owned sector the party was not only omnipresent but in most cases dominant in the firms' management. With the growth of the private and hybrid sectors, however, the party's presence has been reduced quite dramatically. While the total number of party members has developed proportionally with the increase of population (June 2002: 66.4 million members, which equals about 5 percent of the population), the CCP's organizational reach has been shrinking significantly in the growing private sector of the economy. As the establishment of CCP grassroots organizations has not been obligatory here, the mobilizational capacity of the party seem to have been severely reduced in this sector. With it, the party has, over the years, been cut off from access to ever larger parts of the country's workforce.

To tackle this problem, Jiang Zemin announced in May 2000 that party grassroots organizations should be established in those firms of the nonpublic economy where 'conditions were ripe'. ${ }^{49}$ According to the plans of the CCP's Organization Department, enterprises with at least three party members among their employees were expected to establish a CCP grassroots organization (jiceng zuzhi), those with more than three but less than 50 party members should form a regular party branch (dang zhibu), and those with more than 50 party members should establish a general branch (zong zhibu). If 'conditions were not ripe yet', trade unions, youth leagues and other mass organizations' branches should be set up first to pave the way for the later establishment of party cells in private firms. ${ }^{50}$

According to an article published in Zhonggongdangshi yanjiu in the autumn of 2001, among the 1.76 million private enterprises registered in late 2000, 86 percent had no party members among their employees at all, and only 0.9 percent had established CCP grassroots organizations in their firms. The author lists various reasons for this dire situation: First of all, it is hard for party organizations in private enterprises 
to play their proper role. Although some firms have established party cells, they did so only to get access to party channels for the recruitment of qualified personnel; some party cells were 'dependent on the entrepreneur' (yifu yu qiyezhu) - obviously a euphemism for being an instrument of the entrepreneur - while others existed on paper only. ${ }^{51}$

The case of Zhang Ruimin, director of the famous Hai'er joint stock company, is a case in point: When asked by a foreign journalist about who was the party secretary in his company, and whether there weren't any contradictions between the party's goals and the shareholders' interests, Zhang replied: 'Well, the party secretary, that's me ... there won't ever arise any contradictions, 'cause how can I be in contradiction with myself?'52 Our own interviews with private and 'red-hat' (hongmao) entrepreneurs in Jiangsu in May 2001 have revealed that this type of entrepreneur-cum-party secretary has indeed become quite widespread in recent years. ${ }^{53}$ Thus, often, where there are party cells, they seem to be instrumentalized as a mere management tool by the laoban, the 'boss'. In a sense, one can recognize here a strategy of 'counter co-optation' where the entrepreneur co-opts the party in order to safeguard the organizational stability of his firm.

The Zhonggongdangshi yanjiu article offers another reason for the troubles of establishing party cells in private firms, which is the 'incomplete ideological understanding' (sixiang renshi bu daowei) on the side of some party members. For example, some believe (wrongly, of course) that the principle of striving for profits is fundamentally incompatible with the overall goals of the party, and therefore lack self-confidence to do a good party-building job. Others believe that although private entrepreneurs have experienced a rapid development, they still hold a marginal position in social respects. From this perspective therefore, whether party organizations are active there or not does not really matter so much. Still others believe (again, wrongly) that private entrepreneurs only strive for economic success and do not care at all about the development of party cells.

On the side of the private entrepreneurs, the article finds the following 'one-sided opinions' which can be explained by their 'different personal backgrounds and knowledge levels': First, some entrepreneurs fear that party grassroots organizations, once they are established in their firm, could 'use their political influence to interfere with the economic decision-making and disturb the regular production order of the firm, thus impairing the profit goals'. Second, some believe that there are too many non-economic activities being initiated by grassroots or- 
ganizations, increasing the financial burden and driving up the firm's expenditures. Third, some associate the party mainly with lavish banquets, red-tape and corruption in general and therefore 'have no trust in the party' (dui dang mei you xinrengan) - a peculiar reversal of orthodox party members' fear that admitting private entrepreneurs into the CCP could increase corruption. ${ }^{54}$

As these observations demonstrate, the author is quite sensitive to the potential barriers hindering the establishment of party grassroots organizations in private enterprises. The precautions found on the side of entrepreneurs seem all the more realistic as the prescribed tasks of party organizations in private firms comprise not only ideological education and the protection and mediation of workers' interests, but also participation in the firm's decision-making on crucial production and operation matters. The article emphasizes over and over again that the party organizations, in order to win the trust of the entrepreneurs, should refrain from old-style 'commandism', bureaucratic interference and compulsion. Rather, they should play a participatory role by making suggestions and giving advice, co-operating with the management to ensure a healthy development of the firm. The relation between party organization and entrepreneur should not be 'hierarchical' (dengji) or 'antagonistic' (duili), but rather one of 'compatibility' (xiangrong) - whatever this might signify in terms of power relations.

What we find in this description is a potential source of growing problems, tensions and contradictions between the laoban and party representatives inside private enterprises. As the article states explicitly, if the entrepreneur is not willing to recruit party members as employees, he cannot be forced to do so. Thus, to attain the goal of establishing party cells and increase the CCP's organizational presence in private companies, it is crucial to win the sympathy of the entrepreneurs at first hand.

The nexus between the inclusion of entrepreneurs and the mobilization of private sector's workforce outlined seems very important and might have significantly motivated Jiang Zemin's July speech: While the co-optation of private entrepreneurs into the CCP is often seen to work at the expense of the traditional focus of party-building on workers and peasants, ${ }^{55}$ one could also make the reverse argument: In line with the logic just presented, co-optation of the new elites is not so much an end in itself, but rather a necessary precondition for ensuring the continued success of traditional party-building measures among the working masses. As an ever larger share of the country's workers is and will be employed by the private or hybrid sector of the economy, the 
CCP needs to secure its foothold in these sectors in order to gain access to these parts of the workforce. In this sense, co-opting the new 'management labourers' can be seen as the best and only strategy for the party to reach out to the masses of the 'basic labourers' who otherwise would go astray. Paradoxical though it may sound, in order to uphold its nature as the 'vanguard of the working class', the CCP might have decided to tolerate 'capitalists' within its own ranks.

\section{Conclusion: What We Do Not Know}

Concluding this paper, it would be a very satisfying thing to sum up the results and use them to philosophize about the outlook for the party's future development. Suitable topics for discussion might include: the possible evolution of the CCP into a 'people's party' or whatever other labels one might invent; the change in the party's identity and the ideological and psychological reverberations of this change; the future political role of entrepreneurs and other new economic elites; or the prospects for democracy inside and outside the party. However, for the time being, it seems premature to tackle these 'big questions' when our knowledge of the 'small questions' remains insufficient. Thus, as I hope to have shown, some assumptions concerning basic concepts and categories of the 'private sector', as well as motives and strategies of the party, should be (re-)tested on the microscopic level before drawing macropolitical conclusions. According to my understanding, conceptual vagueness or insufficient knowledge prevails regarding the following aspects:

- The concepts of 'private sector', 'private entrepreneur' etc. are not such clear notions in Chinese discourse as the English-language media coverage seems to suggest. This is not only due to statistical inconsistencies, but, more importantly, to inbuilt incentives for actors in the Chinese political economy to disguise what is 'private'. Looking only at the formal private sector (getihu and siying qiye) seems substantially to misrepresent the dynamics of entrepreneurial activities. Therefore, it would be highly desirable to get more concrete insights into the hybrid public-private sectors of the economy, particularly at the local level, and to understand better which among the various types of entrepreneur-managers the CCP in fact wishes to co-opt.

- To speak of 'private entrepreneurs' as a homogeneous group, suggesting that they have similar backgrounds and pursue consistent interests and strategies, seems to ignore the large 
divergencies in personal, educational and occupational backgrounds of entrepreneurs as well as in their attitudes and behaviour. Therefore, the notion of an emerging 'middle class' seems somewhat premature, particularly if it is ascribed the mythical role of a harbinger of pluralist democracy. Before lumping everybody together to form a 'bourgeoisie with Chinese characteristics', it seems more promising to analyse in more detail the variations in backgrounds, interests and strategies among the different groups of entrepreneurs and managers active in present-day China. Some recent studies of social scientists inside and outside China have done pioneering work in this field which can form a fundament for further research.

- Analysing the CCP's strategies of inclusion, we should take into account the various modes of co-optation and organizational linkage which exist inside and outside the party (as scholars such as Bruce Dickson, Thomas Heberer, Kellee Tsai, Zheng Yongnian and others have already been doing). To remind ourselves, various formal channels of political representation of entrepreneurial interests have already been in existence for many years, such as serving as delegates in people's congresses and political consultative congresses, or lobbying through business associations and mass organizations. Realizing that most entrepreneurs who have been politically active via these channels are already CCP members, the question arises how the admission of more entrepreneurs into the party will impact on those formal channels of participation. Will party membership of new groups of entrepreneurs indeed increase their leverage, or will it merely duplicate existing structures of political participation?

- Besides the formal channels, there are many informal ways of representating group interests, which entrepreneurs seem to have found effective in the past. Among them are, of course, various timehonoured networking (guanxi) strategies, but also some innovative methods. The emergence of the 'private entrepreneur-cum-party secretary model' is but one example of what I would call a 'counter co-optation' strategy pursued by entrepreneurs to cope with the CCP's co-optation strategy. If we want to understand the motives and strategies behind the party's attitude toward entrepreneurs, we should analyse the entrepreneurs' motives and strategies as well. Hopefully in the wake of the 16th Party Congress, when more entrepreneurs might be admitted into the CCP, more detailed information will become available about their role in the game. 
Dr. Heike Holbig is a Research Fellow at the Institute of Asian Affairs in Hamburg, Germany.

\section{Notes}

1 Zhang Dejiang, 'Several Issues to be Studied and Resolved in Strengthening the Work of Party Building in Non-public Enterprises', originally published in Dangjian yanjiu [Research on Party Building], no. 4 (2000), excerpted in Zhenli de zhuiqiu [Pursuit of Truth] (May 2001), translated in BBC Monitoring Global Newsline Asia Pacific Political File, 15 July 2001; Lin Yanzhi, 'How the Communist Party Should "Lead" the Capitalist Class', in Shehui kexue zhanxian [Social Sciences Battlefront] (June 2001), translated in BBC Monitoring Global Newsline Asia Pacific Political File, 16 July 2001, Deng Liqun et al., 'Deng Liqun dengren pi Jiang Zemin gongkai xin' (Open Letter by Deng Liqun and Others Critizing Jiang Zemin), unpublished document, cited by Joseph Fewsmith, 'Is Political Reform Ahead? - Beijing Confronts Problems Facing Society - and the CCP', China Leadership Monitor, no. 1 (2002), p. 9 , fn. 8. The contents of these critical articles have been purported widely; cf. Fewsmith, 'Is Political Reform Ahead? - Beijing Confronts Problems Facing Society-and the CCP'; Heike Holbig, 'Die KPCh öffnet sich für Privatunternehmer. Jiang Zemins theoretischer "Durchbruch" und die praktischen Konsequenzen' [The CCP Opens Its Doors to Private Entrepreneurs: Jiang Zemin's Theoretical „Breakthrough" and the Practical Consequences], China aktuell, no. 7 (2001), pp. 739-46; see also Zheng Yongnian, 'Interests, Interest Representation and the Transformation of the Chinese Communist Party'. Paper prepared for the conference 'Bringing the Party Back In: How China is Governed' held in Copenhagen, June 2002.

2 http://english.peopledaily.com.cn/200204/07/print20020407_93626.html.

3 Renmin ribao [People's Daily] website, 19 March 2002.

4 Zhongguo tongji nianjian 2001 [China Statistical Yearbook 2001] (Beijing: Zhongguo tongji chubanshe, 2001), pp. 128-31.

5 Lu Xueyi (ed.), Dangdai Zhongguo shehui jieceng yanjiu baogao [Research Report on Social Strata in Contemporary China] (Beijing: Shehui kexue wenxian chubanshe, 2001), pp. 21315. I would like to thank Torstein Hjellum and Kjeld Erik Brodsgaard for making the report available to me.

6 Zhongguo tongji nianjian 2000, p. 140; Zhongguo tongji nianjian 2001, p. 131; Renmin ribao website, 19 March 2002.

7 For example, Zhang Yuanbao, 'Xiang shehui youxiu fenzi zhangkai damen shi jiaqiang dang de jianshe de zhanlüe jucuo' [To Open the Doors Wide to Outstanding Elements of Society is a Strategic Move to Strengthen Party Building], Zhonggongdangshi yanjiu [Research on the CCP's Contemporary History], no. 6 (2001), p. 11.

8 Zhongguo tongji nianjian 2000, pp. 138, 140; Zhongguo tongji nianjian 2001, pp. 130, 133; Renmin ribao website, 19 March 2002.

9 Renmin ribao website, 19 March 2002.

10 Zhang Yuanbao, 'Xiang shehui youxiu fenzi zhangkai damen shi jiaqiang dang de jianshe de zhanlüe jucuo', pp. 10-15; see also Xinhua News Agency, 22 May 2002; even if the official figures for private entrepreneurs and self-employed entrepreneurs, whose incomes are generated on the private economy, are included in the term 'jiuye renshu', this would only amount to 102.26 million persons for late 2000 - still a large gap to the figure of 130 million.

11 Zhongguo tongji nianjian 2001, p. 132.

12 Four sampling surveys conducted by the CCP United Front Department, the All-China Federation of Industry and Commerce, the China Private Economy Research Group and 
the Chinese Academy of Social Sciences since 1993 are mentioned in Lu Xueyi, Dangdai Zhongguo shehui jieceng yanjiu baogao, pp. 216-17.

13 See, for example, Renmin ribao, 19 March 2002.

14 Zhang Yuanbao, 'Xiang shehui youxiu fenzi zhangkai damen shi jiaqiang dang de jianshe de zhanlüe jucuo'.

15 See International Finance Corporation (IFC), China's Emerging Private Enterprises. Prospects fot the New Century, (Washington, DC: IFC, 2000), pp. 7-44; Organization for Economic Cooperation and Development, China in the Global Economy. Reforming China's Enterprises, (Paris: OECD, 2000), pp. 17-32; interviews with private entrepreneurs conducted with Thomas Reichenbach in Wuxi, May 2001. Thomas Reichenbach is my project partner in a research project on the All-China Federation of Industry and Commerce and its role in the changing structures of interest representation of entrepreneurs in various regions of China. The project, which is funded by the Volkswagen Stiftung, commenced in April 2000.

16 See, for example, 'Report on expanding SMEs' in Zhongguo jingji shibao [China Economic Times], 19 April 2001, p. 7; Xinhua News Agency, 20 February 2002, 26 June 2002.

17 DavidS.G. Goodman, 'The Emerging Public Sector in Shanxi. Entrepreneurs and Enterprise as Risk under Reform'. Paper prepared for UNSW-UTS Centre for Research on Provincial China, Provincial China Workshop, Taiyuan, October 2000, pp. 7-11. I would like to thank Prof. Goodman for making the paper available to me.

18 Ibid., p. 5.

19 Email correspondence with Prof. Andrew G. Walder in May 2002; percentages cited from Bruce Dickson, 'Economics as the Central Task: Do Entrepreneurs Matter?' Paper prepared for the 'China's Leadership Transition: Prospects and Implications' conference, Virginia, December 2001, p. 20, fn. 9. I would like to thank Prof. Walder and Prof. Dickson for sharing their data.

20 Data obtained from my project partner Thomas Reichenbach.

21 Cited by Ignatius Wibowo, 'Party Recruitment and the Future of the Chinese Communist Party', EAI Background Brief No. 101 (September 2001).

22 Dickson, 'Economics as the Central Task', pp. 13-15, and seperate Table 5.

23 This is a term used in a recently published party source: Shi Zhongquan et al., 'Guanyu youxiu qiyezhu rudang wenti de diaocha' [Investigation into the question of outstanding entrepreneurs joining the CCP], Zhonggong dangshi yanjiu, no. 3 (2002), pp. 66-75.

24 Cf. Thomas Heberer, 'Die Privatwirtschaft als Wachstumsmotor. Weshalb öffnet sich die Kommunistische Partei Chinas privaten Unternehmern?' [The Private Economy as Motor of Growth. Why Does the CCP Open Its Doors to Private Entrepreneurs?], Frankfurter Algemeiner Zeitung, 25 March 2002, p. 8; Yeguang Xinwen, 17 August 2001, accessed 24 May 2002 via: news.1chinastar.com/news.shtml?l=chinese\&a=express\&p=1090047.

25 Cited from the official English translation by Xinhua News Agency, 1 July 2001, section 29.

26 Goodman, 'The Emerging Public Sector in Shanxi', p. 17.

27 Lu Xueyi, Dangdai Zhongguo shehui jieceng yanjiu baogao, p. 36; an overview of the report is given in the Hong Kong monthly Guangjiaojing, no. 2 (2002), pp. 14-17; and no. 3(2002), pp. 14-17; see also The Straits Times, 15 May 2002.

28 Washington Post, 31 October 1987. See also Fewsmith, 'Is Political Reform Ahead?'.

29 Interestingly, the 'three benefits' theory of Deng Xiaoping has been cited in recent articles in the official press. See, for example, Renmin ribao, 19 March 2002; Zhonggong dangshi yanjiu, no. 5 (2001), p. 52.

30 For an analysis of the 'three representations' concept, see Holbig, 'Die KPCh öffnet sich für Privatunternehmer'.

31 'New SocialStrata Play Bigger Rolein China's Economic Development', Qiushi, 16 November 2001, translated in BBC Monitoring Global Newsline Asia Pacific Political File, 4 December 2001. 
32 English translation by Xinhua News Agency, 1 July 2001, p. 29.

33 Xinhua, 28 August 2001, cited from news.1chinastar.com/news.shtmal?1=chinese $\& a=$ express\& $\mathrm{p}=1092012$ (visited 12 May 2002).

34 Song Haiqing, 'Zenyang lijie nengfou zijue de wei shixian dang de luxian he gangling er fendou, shifou fuhe dangyuan tiaojian, she xishou xin dangyuan de zhuyao biazhun?' [How to Understand that the Most Important Criteria for Absorbing New Party Members are Whether They Struggle Wholeheartedly for the Implementation of the Party's Line and Programme and Whether They Meet the Requirements for Party Membership?], Qiushi, no. 22 (16 November 2001), pp. 35-36.

35 See Børge Bakken, 'Norms, Values and Cynical Games with Party Ideology'. Paper presented at the conference 'Bringing the Party Back In: How China is Governed' in Copenhagen, June 2002, pp. $14 \mathrm{ff}$.

36 For the use of this new concept see Lu Xueyi, Dangdai Zhongguo shehui jieceng yanjiu baogao, pp. 233-38; South China Morning Post, 30 July 2002.

37 Torstein Hjellum, 'Features of Capitalism and the Restructuring of Ruling Classes in China', The Copenhagen Journal of Asian Studies, no. 14 (2001). Accessible via: www.uib.no/people/ sspth/CapitalistclassChina.htm (visited on 21 May 2002).

38 See Bakken, 'Norms, Values, and Cynical Games with Party Ideology', p. 33.

39 Information from interviews with private entrepreneurs and representatives from All-China Federation of Industry and Commerce subsidiaries in May 2001.

$40 \mathrm{Hu}$ Angang (ed.), Zhongguo tiaozhan fubai [Challenging Corruption in China] (Hangzhou: Zhejiang renmin chubanshe, 2001), pp. 49-50; see also, Lu Xueyi, Dangdai Zhongguo shehui jieceng yanjiu baogao, p. 215.

41 Increasing corruption is one of the consequences Zheng Yongnian sees as arising from the admittance of private entrepreneurs into the CCP; see Zheng Yongnian, 'Interests, Interest Representation and the Transformation of the Chinese Communist Party'.

42 Lu Xueyi, Dangdai Zhongguo shehui jieceng yanjiu baogao, pp. 242-43.

43 Definition by Philip Selznick, cited from Ignatius Wibowo, 'Inducting Capitalists into the CCP: A Case of Hobson's Choice', EAI Bulletin, vol. 3, no. 2 (September 2001), pp. 1-2; see also Bruce J. Dickson, 'Cooptation and Corporatism in China: The Logic of Party Adaptation', Political Science Quarterly, vol. 114, no. 4 (Winter 2000/01), pp. 517-40.

44 Ibid.; similar arguments can be found widely in the secondary literature.

45 Zhang Yuanbao, 'Xiang shehui youxiu fenzi zhangkai damen shi jiaqiang dang de jianshe de zhanlüe jucuo", pp.10-11.

46 Dickson, 'Economics as the Central Task', p. 4.

47 Lu Xueyi, Dangdai Zhongguo shehui jieceng yanjiu baogao, pp. 219-24.

48 Dickson, 'Economics as the Central Task,' p. 16.

49 Xinhua News Agency, 16 May 2000.

50 Cited from Yin Fuying, 'Jiaqiang siying qiye dangjian gongzuo, cujin siying jingii jiankang fazhan' [Strengthen Party Building in Private Enterprises and Promote the Healthy Development of the Private Economy], Zhonggong dangshi yanjiu, no. 5 (2001), pp. 51-56, at p. 53.

51 Ibid., p. 51.

52 'Hai'er: Dangyuan laoban bu maodun' [Hai'er: Being a Party Member Boss is not a Contradiction], Yeguang xinwen, 5 July 2001, accessible via: http:/ /news.1chinastar.com/ news.shtml?1_fanti\&a=express\&p=1081115 (visited on 24 May 2002).

53 Interviews conducted with my project partner Thomas Reichenbach in May 2001.

54 Yin Fuying, 'Jiaqiang siying qiye dangjian gongzuo,' pp. 51-52.

55 Similar arguments are made by Dickson, 'Economics as the Central Task', p. 15, or by Bakken, 'Norms, Values and Cynical Games'. 